\title{
Anthrovision
}

Vaneasa Online Journal

\section{Ecologies of Belonging and the Mugshot Aesthetics}

\section{Cristina Grasseni}

\section{(2) OpenEdition \\ Journals}

Electronic version

URL: http://journals.openedition.org/anthrovision/2845

DOI: 10.4000/anthrovision.2845

ISSN: 2198-6754

\section{Publisher}

VANEASA - Visual Anthropology Network of European Association of Social Anthropologists

\section{Electronic reference}

Cristina Grasseni, «Ecologies of Belonging and the Mugshot Aesthetics », Anthrovision [Online], 5.2 | 2017, Online since 31 December 2017, connection on 01 May 2019. URL : http:// journals.openedition.org/anthrovision/2845 ; DOI : 10.4000/anthrovision.2845

This text was automatically generated on 1 May 2019.

(c) Anthrovision 


\title{
Ecologies of Belonging and the Mugshot Aesthetics
}

\author{
Cristina Grasseni
}

This work was supported by the Radcliffe Institute for Advanced Study at Harvard University through the David and Roberta Logie Fellowship and Radcliffe-Harvard Film Study Center Fellowship, 2011-2012. I wish to thank the following persons who, at various stages of my research, have engaged with me in explorative conversations: Naor Ben-Yehoyada, Arik Bernstein, Augusto Ferraiuolo, Michael Herzfeld, Roee Lotan, Ildikó Plajas, Joanne Rappaport, Federico De Musso, and finally at the Radcliffe Institute Judith Vichniac (Fellowship Program Director), Ellen Shea (librarian), Ivy Yan and Abigail Schoenberg (junior research partners). These methodological reflections are an ongoing part the project 'Food citizens? Collective food procurement in European cities: solidarity and diversity, skills and scale. This project receives funding from the European Research Council (ERC) under the European Union's Horizon 2020 research and innovation programme (Grant agreement No. 724151).

\section{The Enchantment of Making-believe ${ }^{1}$}

1 In the face of present-day fully-automated delirium of digital visual evidence, it is important to recognize how evidence is not exclusively the product of 'technologies of belonging'(M'Charek et al. 2014a, cf. Haraway 1991). ${ }^{2}$ My thesis is that expectations of evidence are saliently embedded in 'ecologies of belonging'. I will conclude that technological devices many confirm or deconstruct, propagate or localize folk categorization and stereotypical expectations about, amongst other, ethnicity and race but do not create them.

2 Based on an ethnographic approach as well as on cultural critique of relevant digital projects, this article confronts visual 'ecologies of belonging'. This builds on my work on skilled visions: looking is a culturally situated capacity that is learnt, embodied, and socialized in specific ways in thickly layered material and socio-historical contexts. As such, skilled visions are both historical and phenomenological, social and embodied. This realization allows us to investigate ethnographically multiple 'ecologies of belonging' 
because a 'skilled vision approach' requires taking vision as a daily practice of competent looking (Grasseni 2018). In other words, socialized perceptual apprenticeship shapes and articulates not only the way in which we sense the world but an entire ecology of belonging. By this expression I mean both the sociocultural and the material environment that configures and gives meaning to what it is like to belong to a specific community of people who share the same skilled vision. For example skilled practitioners share, often tacitly, certain techniques, sensibilities, and postures that inform their ways of looking. Just as an apprenticeship of skilled vision does not deal with the eye alone, but also with a concurrent multi-sensorial enskilment, so ecologies of belonging are not only limited to communities of specialist practitioners or professionals. They include the stereotypes and expectations that one learns when one orients oneself in the world.

Building on this approach, I propose a critical study of the everyday visual apprenticeship of social and cultural stereotypes about looking at others, and at one selves. The main tenet of this piece is that the act of looking and categorizing self and others should be understood as a form of relational and situated learning, rather than as a problem of (facial) recognition. The self-assertion with which we orient ourselves in a social environment on an everyday basis is telling of the enchanted quality of 'making-believe' of what I call 'mugshot aesthetics'. The mugshot view reduces our social abilities of reading complex histories and cultural cues to standard mechanisms, 'makes us believe' that a perspicuous view of human types is achievable, and indeed operationalizable in technologies of vision. However, the evidence of mugshot aesthetics is at best ambivalent. The article proposes a more complex attitude to the issue of recognizing and categorizing self and others, based on fieldwork, in-depth interviews and visual analysis of digital artefacts, concluding that the confidence of our own skilled vision makes us believe that it is indeed possible to sort and chart sociocultural groups on the basis of phenotypic classifications.

4 In what follows, I connect techniques of make-believe and skilled visions as collective practices that make the fuzzy business of categorizing self and others possible.

In the age of our digital "period's eye" (Baxandall 1988), folk physiognomies seep into everyday comparing, for instance in bureaucratic categorizations or collective selfascriptions of ethnicity. At a time when the notion and even the technology of facial recognition is increasingly naturalized, I complicate this by focussing on ecologies of belonging and a socio-historical context shaped by segregation and discrimination. How far have we moved away from Lombroso in our capacity to understand and see through social inculcation when we read others physiognomically? How much is left to personal strategies and collective conventions, negotiating clothing, body language and sociality? How do we learn and inculcate the capacity to read these clues? And how much of these social skills can be regimented in biometric measuring? How much does this impinge into the nature of comparing?

\section{The Ambivalence of Evidence}

6 An ethnographic anecdote will allow me to begin answering these questions by challenging the transparency of evidence in the daily practice of identity ascriptions. In late August 2011, I was freshly beginning fieldwork in Boston, Massachusetts: with my children and husband, I was in the middle of crowded celebrations in the North End Boston's Little Italy - as this Italian American community takes the statues of St. Lucy and 
Saint Anthony in a door to door procession, petitioning the saint with votive offerings (see De Musso and Grasseni 2016). After dutifully making contact with the Feast's organizers on Facebook (I am subscriber number 2003 of the St. Anthony's Feast group), we had 'seen the Saint' in the chapel on Endicott Street, followed the procession with the marching band, attended Mass in the street, bought treats and cannoli, pinned dollar bills on the Saint, and were now on Hanover Street. We thought it was the right time to cross over and go home, as the children were tired. But as we stepped across Cross Street and moved towards the park sitting on top of what the locals call 'the Big Dig', my husband was approached by a man who introduced himself as an Irish retired Catholic priest. He apologised for following us: he wanted to talk to us. He was curious to know how on earth we fitted in the scene we had just abandoned, since we obviously did not look Italian! He commented that my "readiness to smile" gave me away as Irish, my husband was obviously not Italian (he is actually British, of Indian descent) and my children, "redhaired with freckles" certainly looked more Irish than Italian... (my then very young children were blonder than they are now, but did not have freckles).

7 My explorative project Skilled Visions: Critical Ecologies of Belonging was about how we come to formulate these kind of folk-categorizations (being 'Irish' rather than 'looking Italian' in a contemporary American city, for example), how we connect them with naturalized expectations of belonging, and how we learn to ascribe them to ourselves and others. How do we come to make assumptions of people we meet and how do we categorize others? Visual framing as a practice of racial stereotyping relates to timely topics and builds on a sizeable scholarship across the disciplines, to the point of generating conceptual cacophony. ${ }^{3}$ The "skilled visions" approach (Grasseni 2018) focusses on the social processing of visual cues picked up in a complex sensorial and semiotic context. Learning to detect these clues synaesthetically in a relational and material environment is a complex social skill. In other words, the capacity to detect and interpret cues from our environment in order to categorize, identify and 'sort' others is a situated practice, an everyday competence that we develop socially and apply daily, with confidence. It is a fuzzy, ambivalent and often tacit competence - in fact when we try to get at a coherent corpus of knowledge, we encounter the same problems than in the analysis of skill.

Skill is a contested notion: skilled experience is necessary to learning, and deskilling is consequently a political condition that facilitates individualization and dependence. On the latest aspect, critics have underlined how the public enrolment of citizens' skills as forms of societal participation may in fact underscore neoliberal models of self-reliance (Herzfeld 2007, Urciuoli 2008, Gieser 2014). In the realm of skilled visions, we find ambiguities, paradoxes and fuzzy sets. We also enter the sensitive grounds of what Michael Herzfeld has called "cultural intimacy". Cultural intimacy is, in his words, "the recognition of those aspects of a cultural identity that are considered a source of external embarrassment but that nevertheless provide insiders with their assurance of common sociality..." (2005: 3). Cultural intimacies are at work when we categorize self and other. 'Sorting others' does not happen through lucid, analytic categorization but in terms of an ecological analysis: we use our eyes and senses as well as our cultural capacity to make out cues, to find signposts in a social landscape - whether familiar or, even more so, unfamiliar. Skilled vision is a social technique of making believe that grants confidence to our classifications and to our whole ecology of belonging. Looking at each other, we learn to look out for something undefinable albeit specific, something that needs a cultural 
code in order to make sense of it. Looking at each others, we look for something distinctive yet fuzzy, a logic that allows for paradoxes, exceptions, and smudgy edges.

To appreciate skilled vision, we need to consider how we learn to look around us and orient ourselves in a social world: we learn to 'look around' in specific ways, and often this apprenticeship is monitored by peers and instructors who comment, hint, nudge or chastise certain ways of acting or interpreting what is around us. This is proven for example in case of parenting and its important role in orienting children to gendered patterns of interaction with objects (especially toys) around them (Mesman and Groeneveld 2018). Looking is a technique of the body in the Maussian sense - it is not a cognitively acquired skill but a social one, that one learns to exercise in social institutions. The most evident examples of skilled vision are its public performances. Drawing from my ethnographic fieldwork with dairy farmers in the Italian Alps, I have often made the example of cattle inspectors performing as judge at a cattle fair. In this arena, the cattle expert is publicly performing skilled vision - exercised every day in more menial contexts (farms and sheds) to evaluate cattle from morphological and functional viewpoints (and ultimately to evaluate their potential to produce offspring who will in turn be optimal milk producers). An inspector's judgement sets standards for farmers. Similarly, the judge in a cattle fair sets a public standard for the professional audience to apply to their own cattle. So what we actually see when witnessing a cattle competition is the equivalent of a Distinguished Lecture: a microphone and rhetorical techniques of persuasion are employed to make the audience believe that the first prize is towering over the second prize for good reasons, the second over the third, and so on. The professional discourse is that of traits selection for progeny breeding (Grasseni 2007a). This professional discourse is mediated through the sharing of a professional skilled vision within a community of practitioners who agree on parameters of production, economic stakes, and ultimately an aesthetic and moral canon of belonging to the Brown Breed association.

10 Any such type of "schooling of the eye" is a social, cognitive and relational enterprise: these processes of apprenticeship are ubiquitous, specific to contexts and often telling of those contexts. In my work on skilled visions, I gathered ethnographies of visual apprenticeship from fellow ethnographers and scholars in other disciplines. Skilled Visions (2007b) thus gathers case studies conducted in high and low-tech contexts, mostly professional: architects, urban planners, medical laboratories, medical schools, but also $18^{\text {th }}$ century botanists' cabinets and contemporary 'drag' clubs. My question to my fellow ethnographers was: how is consensus achieved in all these different cases on what is beauty, propriety, and exactness? The answers point to locally defined rules, namely the fact that rules about beauty, propriety and exactness are negotiated and enforced locally, within a circle of practitioners.

11 It is not only in professional contexts that classifying, just as much as being categorized by others, is part and parcel of an everyday 'ecology of practice'. Building on my work with Francesco Ronzon on 'ecology of culture' (Grasseni and Ronzon 2004), by 'ecology of belonging' I mean the tight link between practice and cognition. Body, mind and cultural expectations grow together in fields of practice - as taught by Tim Ingold in his earlier work on the anthropology of the environment. By taskscape (1993: 158), he indicated a task-oriented horizon that orients daily practice in a familiar environment. Landscape and practice are tightly interwoven in a taskscape, a sensorial and relational space in which we are always immersed. Not only tasks but gender roles and status also arrange both our 
relational and material landscapes: for example, common-sense expectations about whom one meets in the street are (still) informed by (racial) stereotyping.. ${ }^{4}$ argue that focalizing on the synesthetic and semiotic complexity of the act of looking ('looking around') may enhance our understanding of the cultural-and-relational-and-embodied reactions through which stereotypes, ideologies and hegemonic discourse inform our ecologies of belonging.

This literally responds to the challenge of "re-focalizing the ethnographic gaze on the production of ideological sentiments" (Herzfeld 2012). The banality of the everyday digital 'clutter' brings plenty of ethnographic material to speak to this question. On the web, I have singled out four sites that display, make use or problematize the skill of looking at and categorizing other people. In all of them, the perspicuity of skilled vision is associated with a problem of facial recognition - or with a face-centred aesthetics that I call 'mugshot aesthetics'. In the following section I will analyse the sites Alllooksame, Facity, The Hapa Project and This is Us, comparing how they respond to and problematize everyday practices of categorization in terms of 'facial recognition'. I playfully explore the limits and ambivalence of "make-believe" in these digital projects and contrast them with ethnographic practice to clarify what is ambivalent. My conclusion will be that they reduce complex issues of classification - a pervasive, situated and disingenuous practice to a mugshot heuristics, which is implicitly mechanistic. The fuzzy categories vaguely but effectively invoked by the self-defined Irish priest, who (successfully) singled us out in the act of 'not belonging' to an ascribed ecology of sameness, get lost in the process.

\section{Perspicuous Vision and the Mugshot Aesthetics}

13 Alllooksame.com/ is an American website playfully mocking the idea that we need visual expertise to tell different types of Asian nationalities. ${ }^{5}$ The title is a pun on the white stereotype that Asians 'all look the same', so that for example Japanese, Korean and Chinese are indistinguishable to a 'WASP' (white, Anglo-Saxon, Protestant) American. Its author, a Japanese man based in New York, has accompanied the website with a blog about his personal experience of stereotyping. Taking stereotype seriously as a way of making an ironic intervention about it, the site provides an online 'Exam Room' to train the user not only in distinguishing Chinese from Japanese from Korean faces, but also the art, traditional architecture, travel locations, food and urban scenery of each 'nationality' or 'ethnicity'. In his personal blog the author, Dyske Suematsu, uses 'nationality' and 'ethnicity' interchangeably, treating cultural traits and bodily appearance as equivalent pieces of evidence. As a further role-performance, the author states that he set up this website because his (then) girlfriend admitted that she couldn't tell the difference between different Asian types. The idea of solving his wife's 'facial recognition problem' was to set up this website to train users how to determine between Japanese, Chinese, and Korean faces.

14 Challenging the "cosmetic multiculturalism" of digital media (Nakamura 2002a: 21) and the USA's own utopian myth of being a democratic melting pot, Alllooksame mocks an idea of racial levelling that ultimately equates to paternalistic indifference, and uses digital technologies to 'make us believe' that we can actually train online, as in a computer game, learning the basics of culture and physiognomy of Asian 'types'. Significantly, part of this make-believe consists in levelling down to a 'facial recognition problem' the complex skill of recognizing not only faces but other items such as food and 
landscape in a culturally competent way. Less benignly, nationality and ethnicity are also compounded into physiognomic traits.

Much more caustically, Goldberg's pamphlet on "Racial Europeanization" (2006) points to the very different discourse on race that dominates Europe - in fact a taboo on racelanguage. By comparison with the US, which is obviously the cultural arena of reference of Alllooksame, Europe acts 'race-blind'. However, European scholars have denounced how race is an 'absent presence' in European practices of othering, drawing on societal expectations that find confirmation in the active production of 'phenotypic others' through 'technologies of belonging' (M'charek et al. 2014a). What is then the technique through which to unravel how we attribute or negate specific forms of belonging?

According to this website, we need to practice to be able to recognize not only relevant traits in faces, but in art, architecture, scenery, urban landscapes, etc. This would somehow yield a more perspicuous vision, whereby one does recognize Asian types at first sight (and presumably also make one competent on food, cultures and societies of different Asian countries). However, the 'exam room' does not say how practice would make one wiser. Philosopher of language Ludwig Wittgenstein (1953) used the term 'perspicuous' to express his point that different 'language games' become familiar once one masters them in practice; in other words 'rule-following' is a matter of grasping-andapplying the rule in practice rather than being able to articulate it exhaustively. A perspicuous vision of several language games is similar to a comparative analysis that does not measure uniform items trait-by-trait, but grasps similarities and differences of complex objects (such as 'language games' or 'cultures') while also comprehending how they belong to the same fuzzy set - a set with porous boundaries, like a family. In the exam room of Alllooksame, sorting mugshots of different 'types' means being forced to actively reconsider the act of seeing and of categorizing. In this inversion of digital utopias, the project ironically reifies differences rather than eliding them - as a way of 'demystifying the issue' according to the author of the website. However, the pervasiveness of what he calls 'a facial recognition problem' pinpoints the role that visual classification, group categorization and social typification play in our everyday life (cf. Nakamura 2002b).

17 Mugshot aesthetics is a visual trope shared by many social networks. It is played out in websites that deliberately link specific ways of looking with identity, ethnicity or locality. The idea of navigating a face-landscape is epitomized in Facity: a project set up by three photographers in Berlin in 2008, grown (by 2011) to 400 photographers active in 125 cities, posting 4000 photographs of faces. ${ }^{6}$ Photographs are shot in standard ways, with a minimalist mugshot aesthetics (extreme close-up, minimum hair, no make-up or clothes, expressionless attitude). ${ }^{7}$ Most photographs are from Berlin - the initial site - with Tel Aviv as second most numerous site at the time of research. No specific reference is made to the idea of mapping a human landscape, but since the project only accepts portraits on the basis that subjects actually live in the intended city, their faces eventually stand out in diverse patterns, which visually map a human landscape of world cities. This becomes striking by comparing different sites and noticing the dominant skin colours, eye shapes, hair types etc. The matrices in which the mugshots are then composed create distinctive "face landscapes" of any given city, presuming "close, direct, intimate, naked, natural", hence "genuine" representation of face-types. ${ }^{8}$ Perspicuity would be yielded in this case by the overview of comparable faces - all shot in mugshot mode. 

aiming to raise racial awareness and advocate the idea that "I am not what you think I am". ${ }^{9}$ The project provides a digital space for personal stances against stereotypical expectations about Asian typification. The latter project reflects on and critiques mugshot aesthetics, by incorporating it into the site's practice of contestation, as a visual trope for identity based on looks and the performance of (self)-representation. By doing so it problematizes the very fact that we learn to make sense of clues in a context, through accredited social idioms - a practice which Alllooksame ironically embraces and Facity minimalistically elides. The Hapa and other projects take race squarely as a subject of self-investigation and education, also in the framework of digital science popularization programmes such as PBS' online project 'Race - are we so different?' Mugshot aesthetics works here not in relation to policing practices but in artistic appropriations and demystifications of the trope of facial recognition, as an all-too easy deterministic reduction of the work of categorizing self and other. Digital cultures thus confirm that the workings of 'othering' (and 'selfing') have deep roots in the everyday skill and practice of stereotyping, rather than straightforwardly emerging as the 'othering' results of technologies of representation. mapping places through faces: This is Us: The Average Israeli Project. ${ }^{10}$ The video demo posted on Vimeo says "this groundbreaking web project visualizes vital statistics to create an experience which confronts the user with his/her preconceived notions about himself and the people around him. The project maps, tracks and reflects on our basic nature and pre-conceived notions of our being and our nature of comparing". ${ }^{11}$ This is a photographic database of 406 subjects sampled according to age, sex, income, education, location of residence but also 'origin', 'immigration', 'nationality' and 'religion'. I found many parallels with Italy, another country with a strong city/periphery and north/south divide, a citizenship law that draws on descent and not on location at birth to determine one's nationality, and many possible ways to answer the question "where do we come from"? Migration patterns, lineages and location combine in complex ways - to the point that a model picture of the average Italian would be a hazardous abstraction. So many are the differences and variations over geography and history that it would make little sense indeed. Because of this, as in many other cases, the skill to recognize a compatriot abroad, for example, cannot be defined as one of 'facial recognition' as assumed by Alllooksame. Contrary to this rationale, the ethnographic incipit of this article demonstrates that people are expected to fit stereotypical expectations - for example, of what an 'Italian' should look like. While a project like Facity breaks down these expectations, by seeking face-landscapes that are city-based and thus to an extent localized, situated, and concrete, This is Us suggests that average 'types' can be visualized. The mesmerizing possibilities for unexpected as well as stereotypical associations across types are explored by design artist Roee Lotan through a combination of digital media and biometrics.

This is US premiered at the International Documentary Film Festival in Amsterdam in $2010 .{ }^{12}$ The project's site offers several functions, including a cloud view of the entire database (each person in the database being visualized as a mugshot icon) and a sorting tool that groups the icons by Sex, Age, Origin (Oriental or Ashkenazic), Education (by years spent in education: 0-4; 5-12; 13-15; 16+), Location (South, Jerusalem, North, Haifa, Center, or Tel Aviv), Religion (Secular, Traditional and Religious), Nationality (Jewish and Arabic), Immigration (Israelis, Ethopians and Russians), Marital Status, and Income. ${ }^{13}$ The 
data base allows one to 'combine all' the mugshots to obtain a virtual 'average face' which can be gradually changed by sliding between two poles on a digital bar: so for example between a 'Jewish' and an 'Arabic' average face, or between a 'Low Income' and 'High Income' average face. This is Us is an intriguing and opaque project. Should one follow one face across categories and see if its overall profile challenges a stereotype? For example, what are the actual looks of a Russian immigrant, or a resident of a border settlement? Having the good fortune of a contact to the author, after interviewing Arik Bernstein of Alma Films in Tel Aviv, I spoke to Roee Lotan - the author of the web site - on Skype in 2011. The artist explained to me in an in-depth interview that his project This is us maps, tracks, and reflects on our basic nature and preconceived notions - specifically on the urge of comparing. In a key passage of our conversation, we commented on an interview I had previously filmed with Arik Bernstein, a film producer, a few days before, discussing the artist's website. I explained how I was interested in understanding how we learn to develop a certain set of assumptions or presumptions - preconceived notions of other people - through social circles. Roee was clear about the fact that in his opinion this process is 'beyond language' - something much more premature and spontaneous.

21 I explained my conviction that such processes are also context-based. Arik in his interview had challenged me by asking, "Can you tell a Jew?" My reply was that actually I can't, it's not part of my cultural baggage. It's not really relevant to my daily social skills. In response to that, Roee had an interesting question for me: whether I could tell an Italian. I was delighted to answer because I felt that that's exactly what my project was about: I can, I felt I actually can. Roee resonated with that and connected it to the meaning of his website This is Us: 'It represents all the people you meet; it's an abstract exploration of your mind'. I was suspicious of this because the artist had met those particular 406 people, and sorted them according to what they answered to the categories of his questionnaire, which corresponded to certain predefined categories in the national census, so in my opinion the actual face you can digitally 'average' was a serendipitous combination of those 406 actual people he had met in the street and who had agreed to have their photos taken. The artist disagreed, convinced that if he did the same four, five times over, there might be two different actual extremes between one pole and another but not the mean. That would have average out the specificities of actual specimens for the same categories, as in the case of a geologist assembling samples from a mountain. It does not matter which specific samples are gathered: the data talks about that mountain. So similarly 'each group has an archetype. When you walk in the street, you see the businesswoman, the hipster, the artsy people, the student. All these people are archetypes in the sense that they are standing there as icons of something else, they represent a group. ${ }^{14}$

Obviously, the artist cared a lot about this project: he had spent a year working on it, scouting for faces all over Israel, and was adamant that this work was not meant to simply be a digitally crafted object for aesthetic appreciation. In his own work, he had sampled the nation. We continued our conversation about this heavily mediated project - during which the artist had spent four months of hard digital work to match his installation with an actual biometric analysis of the faces he had photographed. Our conversation was less about the facial recognition technology he used, and more about the normative idea of 'sampling the nation'. This conversation was itself mediated by a communication technology - Skype - which allowed us to have a meaningful conversation and an indepth encounter (not devoid of embarrassments and the emotion of self-recognition), 
itself a 'technology of making believe' that we could in fact have a dispassionate conversation from two sides of the planet each coming from disparate disciplinary expertise and labouring under equally charged but certainly different national histories.

What fascinates me about This is us is the fact that it pursues two contradictory objectives, and possibly succeeds in doing so on both accounts. On the one hand, it wants to disembed our capacity to recognize "types" from our stereotypes about them - in fact it challenges social stereotypes about 'immigrants' and associated semantic areas. But on the other end, it does point at "archetypes" as true objects inhabiting our mind, which only need to be properly fore-grounded (to then be critiqued). However, my contention is that we do not make associations by activating a mental database of previous instantiations of the same "types". Our perspicuous vision seems to derive from a different, non-algorithmic and more situated skilled practice of looking.

The work of historical anthropologist Joanne Rappaport (2014) provides reasons for scepticism: studying Spanish descriptions of people in $16^{\text {th }}$ and $17^{\text {th }}$ century New Kingdom of Granada, she highlights how the colonizers were confronted with people they did not know how to categorize and compare. Mestizos, the 'mixed-race' offspring of Spaniards and indigenous populations were object of uncertainty and discursive negotiation. Rappaport explains how, 'physiognomic discourse did not work in the Americas. Crown officials found it impossible to effectively distinguish among Indians using conventions meant to highlight features of importance to Europeans', for whom for example facial hair for instance was so important to demonstrate maturity and social standing (Rappaport 2011: 613). This empasse 'complicates our appreciation of the fit between physical appearance and ethnoracial classification in the early modern Atlantic world, where observers were frequently uncertain about bow to classify individuals' (2011: 629).

Rappaport also points out that physical appearance actually made no conclusive difference to one's placement in a racial hierarchy, as this was dictated by descent rather than phenotype. And again, descent was important for religious purposes and not for calculating ethnicity or degrees of metissage - as in later casta paintings. The expression limpieza de sangre referred to direct descent from Christians rather than converts, not directly to a racial categorization. Rappaport's historical study of racial categorization in its making points out - in her own words - that appearance and descent can 'be calculated independently of one another' (2011: 603). Moreover, racial categories could be reinterpreted and manipulated, and in fact some people classified as mestizos were reclassified as indigenous' in order to ensure their tribute payments. But physical appearance would become an object of analysis when someone's classification (being a true Spaniard or not, for example) was already in dispute. Crucially though, a moment of systematic doubt was created upon entering or exiting the colonies: 'sight at once constituted and was constituted by the process of classification in the colonial Nuevo Reino, visual cues forming part of a colonial habitus through which ethnoracial categories were continuously being reinterpreted in particular social contexts' (2011: 608). Rappaport interrogates textual descriptions written by the early-modern equivalents of our immigration officers, at the moment of border crossing. At this liminal point, physical appearance did become very important as a piece of evidence offered to institutional scrutiny, and had to be recorded in writing upon entrance and exit of the country.

Rappaport finds archival evidence of early modern equivalents of immigration officers screening travellers for further inspection. How did they learn to do that? They certainly were not using what could be considered as an antecedent of our contemporary mugshot 
aesthetics. Only much later did casta paintings - common in the $18^{\text {th }}$ century - succeed in visually ordering Mexico's societal racial hierarchy (Cummins 2006). Casta paintings displayed mixed couples with their - labelled - offspring. White-to-black hues corresponded to a ladder in occupation, social standing, and inclination - so that nature and society were ordered into one naturalized taxonomy. Casta paintings are the best example of visual "evidence" used to inculcate racial categorization (Bleichmar 2007). Nevertheless as Rappaport sums up: 'caste paintings didn't reflect what was out there, but were an idealized representation meant for Iberian eyes. The profusion of discrete categories didn't exist on the ground in the eighteenth century, and even less in the sixteenth. Caste paintings are another place in which we read our own sensibilities into a medium, with predictable results". ${ }^{15}$ The mixed couples of casta paintings, and their categorized offspring - whose place in society is determined by appearance - are the perfect example of how the expectation of finding visual evidence of specific types has infiltrated our own categorization processes and relevant ontologies.

'Evidence' does not reflect what is out there: it creates it while mapping it (Galison and Daston 2008). The border officers of the New Kingdom of Granada did not use synoptic classificatory systems to determine the identity of individuals entering or exiting the colonies. Rappaport thinks that a great deal of what they learnt was absorbed by working in teams with notaries and scribes, so they were following rules of thumb acquired through practice. Even for a society based on violently racist grounds, the act of recognizing and sorting mestizos from indigenous or Spaniards depended on a number of culturally loaded and fuzzy clues: beard, apparel, social indenture, etc. Further historical studies confirm that the fuzzy business of sorting people did not depend exclusively on visual evidence and its objectivity - a characteristic that we have only historically learnt to associate with photography but was not necessarily nor exclusively part of it (Galison and Daston 2008). For example, even before the invention of the photograph, the French and German police promoted standard techniques and methods for the identification of individuals and its documentation. As Peter Becker (2001) shows, this was a historical moment in which the development of modern European states and of its policing bureaucracies and practices motivated and required a standardization, articulation and formalization of policemen's intuitive and savy techniques for 'eyeing up' suspects. In the late $19^{\text {th }}$ century for example, Alphonse Bertillon's portrait parlé provided a physiognomic description based solely on comparison of bodily traits, graphic description and classification. It was meant to homogenize the inquisitive gaze that policemen would otherwise tacitly and probably unselfconsciously apply in practice, based on trained experience (Becker 2001: 142). ${ }^{16}$ This 'standardized gaze' translated the skilled visions of policemen in a classificatory visual artefact which could be then 'mobilized' (in a Latourian sense): the search warrant. On the other hand, the perspicuous vision that the Irish priest was (only half-rightly) applying to me in Boston in the late summer of 2011, quickly figuring out that I did not belong in the North End, but thinking he was recognizing a fellow Irish person, is a similar form of uncodified and unsystematic skilled vision, a complex act of (non)recognition embedded in the very act of looking - a practice that is largely contextual, socially informed and unselfconsciously performed. 


\section{Conclusion}

28 This skill feeds on culturally situated clues and on comparison more than on an archetypal classificatory scheme. The business of "sorting faces" depends on where we draw the implicit boundaries of the groups we are identifying, and this can be ascribed in turn to a form of skilled vision which encompasses fuzzy and context-bound cultural competence. This includes the belief - as a result of relevant techniques of makingbelieve such as the ones I cluster here around what I call 'mugshot aesthetics' - that one does indeed belong to a clear-cut category just as much as others can be equally pilesorted as a mere matter of facial recognition (cf. Bowker and Leigh Star 1999).

Wittgenstein's metaphor of "family resemblance" can be of use here to disambiguate what I mean by fuzzy and context-bound cultural competence. In his Philosophical Investigations, Wittgenstein drew on the resemblances between members of a family to explain how we group together, for instance, different types of games (chess, baseball, hide-and-seek etc.). He says that in family resemblance: "Build, features, eye-colour, gait, temperament, overlap and criss-cross ... And we extend our concept as in spinning a thread we twist fibre on fibre. And the strength of the thread does not reside in the fact that some one fibre runs through its whole length, but in the overlapping of many fibres" (Wittgenstein 1953: § 67). So the result of our grouping does not depend on the objects by themselves, but on the way we group them. To continue with the example of the games family, one can tell that the family resemblance has broken down when something is not a game any more. Likewise, our expectations and categorizations seem fuzzier than archetypes: they allow for category stretching, slippages and exceptions. ${ }^{17}$

Reading my ethnographic encounter with the Irish priest in the North End in the light of this literature requires to add one more tassel to the jigsaw of skilled vision as a social technique of making-believe (that we belong and that others belong to distinctive categories that are recognizable at sight): the social performance of 'cultural intimacy' (Herzfeld 2005). Far from being the result of unconscious applications of tacit logics of classification, ecologies of belonging are a form of cultural intimacy: public and contested, performed and debated. One example of ostensible self-ascription of ethnic categorizations are the many festivals that the Italian American community celebrates in Boston and in East Cambridge between the end of August and the beginning of September, such as the festival in the North End that I was attending with my family when we attracted the gaze of the Irish priest. In brief (see also De Musso and Grasseni, 2016, Grasseni 2014), the Southern Italian tradition of petitioning the patron saint with votive offerings has been transplanted in the States, so that the statue of Saint Anthony may end up carrying 50,000 dollars by the end of a ten-hour, door-to-door procession, from Endicott Street to Hanover Street and back. Augusto Ferraiuolo (2009) has given a thorough historical reconstruction of Bostons's societies of the saints in a book tellingly subtitled Ephemeral Identities in an Italian American Community. Why ephemeral? In these moments of heightened collective performance and self-identification, lineages and attachment to one's village of origin are eagerly self-ascribed - and attempts are made at speaking a language or dialect mostly forgotten or unknown to the new generations. The badges of the devotional saints mark the bearing of that identity, and testify to the offer made. Once the red bricks are left behind though, beyond Hanover street, the same 
badges become a bit embarrassing, meaningless, or exotic. Such displays of belonging seem twice as ephemeral, when locally elected politicians who publicly sponsor the festival say off the record that the idea of an Italian identity is ridiculous, as everyone 'here' is mixed, with an Irish parent or a Jewish one - or Portuguese, or Korean.

The analogy that I want to offer is between the ephemerality of the mugshot and of cultural markers of identity - such as cultural offerings to saints - which, as one walks away from their situated frameworks - become exhausted and even embarrassing, ready to become discarded. Our capacity for recognizing and ascribing membership of a certain group may be in conversation with and heavily shaped by a pervasive 'mugshot aesthetics', but it encompasses something very similar to a rule of thumb, embedded in practice, even though it seems natural to try and find its archetypal equivalent in some sort of logical classification. This is the result of the many enchantments operated on us by pervasive technologies of making-believe, beginning with the photograph and finishing with facial recognition.

Visual technologies carry multiple voices. Documentary film maker Judith MacDougall in her film The Art of Regret (2007), shot in a rapidly urbanizing China over a decade ago, studies changing cultures of visual evidence and the cacophony of narratives crowding digital photos and their application, in a world still innocent of Instagram. Following the encroaching dissemination of digital technologies and photography as increasingly a form of popular culture, she explores the importance of the photography studio and of private archives as the few repositories of pre-cultural revolution memories. Both a "technology of remembering" and a tool to bring forth evidence, photography seems twice removed from enchantment. Documentary evidence can be exposed to further scrutiny and surveillance. However, both symbolically rich, iconic portraits and mugshot photos alike maintain a form of efficacy.

The ambivalent power of the camera as conducive to evidence or to the faking of it (or to the ambiguous coexistence of the two) can also be found in the case of filming, beginning with the famous long-take of Jean Rouch, the cine-trance, but also considering the work of Diego Carpitella and Ernesto De Martino who together recorded staged performances of 'tarantism' (a state of trance induced by a mythical spider bite) in the Apulian Salento. Their performance was staged, but the tarantate were real, and surrealist film-maker Luigi Di Gianni chose to use a fictionalized script to bring forth the authenticity and audacity of tarantismo in the strictly surveilled space of Catholic shrines and rural village life (Di Gianni 1965, see Schäuble 2016). If possession - as Francesco Ronzon (2002) argues in his work on Haiti's voodoo - is a technology of orientation in the world, which makes use of vivid signposts in the everyday and ritual environments to guide, support, and appease otherwise hardly bearable lives, there surely must be space for technologies of self-reprise amidst the delirium of evidence, both within academia and outside, which so much resembles the brave new world of so called evidence-based science, or at least its intent: "a transparently legible and fully governable world, a total world present in objective evidence, including the inner lives of persons" (following Paul Johnson 2015, who describe fetish possession and the new role of photography as mediator, in newly independent Brazil).

34 This historical process of erasure of the ambivalence of evidence and its contextual and comparative nature lends considerable power to the expectations of achieving perspicuous visions not by digging into contexts and comparing them, but rather by abstracting from them to distil archetypes. Photographs are objects that are naturally 
calibrated to the collecting modalities of the archive (Paul Johnson, 2015): they fit the container, so to speak. ${ }^{18}$ Therefore they were more easily handed down, propagated, and ultimately empowered with the voice of evidence. Similarly the mugshot aesthetics of the websites I commented fits snugly the cultural expectations and the language of categorization that scientific common sense uses to operationalize the enchantment of folk categorization, rather than to dwell on the salience, origin and workings of ecologies of belonging.

\section{BIBLIOGRAPHY}

Austin, John. 1956. A Plea for Excuses: The Presidential Address. Proceedings of the Aristotelian Society. New Series 57:1-30.

Baxandall, Michael. 1988. Painting and Experience in Fifteenth-Century Italy. Oxford: Oxford University Press.

Becker, Peter. 2001. The Standardized Gaze: The Standardization of the Search Warrant in Nineteenth-Century Germany. In Documenting Individual Identity: The Development of State Practices in the Modern World. Jane Caplan and John Torpey, eds. Pp. 139-163. Princeton: Princeton University Press.

Bleichmar, Daniela. 2007. Training the Naturalist's Eye in the Eighteenth Century: Perfect Global Visions and Local Blind Spots. In Skilled Visions. Between Apprenticeship and Standards. Cristina Grasseni, ed. Pp. 166-90. Oxford: Berghahn.

Bowker, Geoffrey and Susan Leigh Star. 1999. Sorting Things Out: Classification and its Consequences. Cambridge, MA: MIT Press.

Cummins, Thomas. 2006. Casta Painting: Images of Race in Eighteenth-Century Mexico. Book Review. The Art Bulletin 88(1): 185-96.

De Musso, Federico and Cristina Grasseni. 2016, Picturing Intimacy: Mediation and Selfrepresentation in Boston's Religious Festivals, Anthrovision 4(2): https:// journals.openedition.org/anthrovision/2359 (accessed 29 January, 2019).

Di Gianni, Luigi. 1965. Il Male di San Donato. Roma: Nexus Film.

Ferraiuolo, Augusto. 2009. Religious Festive Practices in Boston's North End:Ephemeral Identities in an Italian American Community. Albany: State University of New York Press.

Galison, Peter and Lorraine Daston. 2008. Objectivity. Cambridge, MA: the MIT Press.

Gieser, Thorsten. 2014. Enskillment Inhibited: Industrial Gardening in Britain. Journal of the Royal Anthropological Institute 20(1): 131-149.

Goldberg, David Theo. 2006. Racial Europeanization. Ethnic and Racial Studies 29(2): 331-364.

Grasseni, Cristina. 2018. Skilled Vision. In The International Encyclopedia of Anthropology. Hilary Callan, ed. Wiley Publishers. 
Grasseni, Cristina. 2014. The Atlas and the Film. Collective Storytelling Through Soundscapes, Sightscapes, and Virtualscapes. Anthrovision 2(2): https://journals.openedition.org/ anthrovision/1446 (accessed 29 January, 2019).

Grasseni, Cristina. 2007a. Managing Cows: An Ethnography of Breeding Practices and Reproductive Technology in Contemporary Dairy Farming. Studies in the History and Philosophy of Biological and Biomedical Sciences 38(2): 488-510.

Grasseni, Cristina, ed. 2007b. Skilled Visions. Between Apprenticeship and Standards. Oxford, New York: Berghahn Books.

Grasseni, Cristina and Francesco Ronzon. 2004. Pratiche e cognizione. Note di ecologia della cultura. Roma: Meltemi.

Haraway, Donna. 1991. A Cyborg Manifesto: Science, Technology, and Socialist Feminism in the Late Twentieth Century. In Simians, Cyborgs and Women: The Reinvention of Nature.Pp.149-181.New York: Routledge.

Herzfeld, Michael. 2005. Cultural Intimacy. Social Poetics in the Nation State. Second Edition. New York: Routledge.

Herzfeld, Michael. 2007. Deskilling, 'Dumbing Down' and the Auditing of Knowledge in the Practical Mastery of Artisans and Academics: An Ethnographer's Response to a Global Problem. In Ways of Knowing: Anthropological Approaches to Crafting Experience and Knowledge. Mark Harris, ed. Pp. 91-110. Oxford: Berghahn Books.

Herzfeld, Michael. 2012. Radici antiche, razzismi recenti: passato, stirpe e lignaggio negli stati nazionali dell'Europa meridionale. In XENOI. Immagine e parola tra razzismi antichi e moderni. A. Cannas, T. Cossu and M. Giuman eds. Pp. 253-266. Napoli: Liguori.

Ingold, Tim. 1993. The Temporality of the Landscape. World Archaeology 25(2): 152-174.

Johnson, Paul. 2015. Photographe, esprit, esprit-photographe. Paper presented at Les Techniques $d u$ (faire) croire, 27-29 May 2015, EHESS Paris. In press, Archives de Sciences Sociales des Religions.

M'charek, Amade, Katharina Schramm, and David Skinner. 2014a. Technologies of Belonging. The Absent Presence of Race in Europe. Science, Technology and Human Values 39(4): 459-467.

M'charek, Amade, Katharina Schramm, and David Skinner. 2014b. Topologies of Race. Doing Territory, Population and Identity in Europe. Science, Technology and Human Values 39(4): 468-487.

Mesman, Judi and Marleen Groeneveld. 2018. Gendered Parenting in Early Childhood: Subtle But Unmistakable if You Know Where to Look. Child Development Perspectives 12(1): 22-27.

Nakamura, Lisa. 2002a. Cybertypes. Race, Ethnicity and Identity on the Internet. New York: Routledge. Nakamura, Lisa. 2002b. Alllooksame? Mediating Visual Cultures of Race on the Web. Iowa Journal of Cultural Studies 2: 73-84.

Rappaport, Joanne. 2014. The Disappearing Mestizo. Configuring Difference in the Colonial New Kingdom of Granada. Durham, NC: Duke University Press.

Rappaport, Joanne. 2011. “Asi lo paresçe por su aspeto”: Physiognomy and the Construction of Difference in Colonial Bogotá. Hispanic American Historical Review 91(4): 601-631.

Ronzon, Francesco. 2002. Ogun, Rambo, St. Jacques. Spiriti, immagini e pratiche cognitive nel vodou di Port-au-Prince (Haiti). Ricerca Folklorica 45: 53-70.

Schäuble, Michaela. 2016. Images of Ecstasy and Affliction. The Camera as Instrument for Researching and Reproducing Choreographies of Deviance in a Southern Italian Spider 
Possession Cult. Anthrovision 4(2): https://journals.openedition.org/anthrovision/2409. (accessed 29 January, 2019).

Shapin, Steven. 2003. Cheese and Late Modernity. Review of Camembert, A National Myth by Pierre Boisard. London Review of Books (11): 11-15.

Urciuoli, Bonnie. 2008. Skills and Selves in the Workplace. American Ethnologist 35(2): 211-228.

_Wittgenstein, Ludwig. 1953. Philosophical Investigations. Oxford: Blackwell.

Film

MacDougall, Judith and Kathy Zhang, dir. 2007. The Art of Regret. Canberra: Centre for Cross Cultural Research. 59 min.

\section{Websites}

Alllooksame? http://alllooksame.com/ (accessed 29 January, 2019).

FACITY http:// http://www.facity.com/ (accessed 29 January, 2019).

Fulbeck, Kip. Hapa Project. https://kipfulbeck.com/the-hapa-project/hapa-about/ (accessed 29 January, 2019).

ThisIsUs. http://thisisus.co.il/ (accessed 29 January, 2019).

\section{NOTES}

1. I wish to thank Nadine Wanono, Charlotte Bigg, Stefania Capone and Nathalie Luca for inviting me as discussant at the EHESS Conference Les Techniques du faire croire in Paris in May 2015. This work builds on reflections sparked by those conversations.

2. In her Cyborg Manifesto, Donna Haraway warns that 'technologies of visualization recall the important cultural practice of hunting with the camera and the deeply predatory nature of a photographic consciousness' (1991: 169).

3. This scholarship includes literature (for example George Eliot's Impressions of Theophrastus Such ), physiognomy (the work of Cesare Lombroso but also Darwin's The Expression of Emotions in Man and Animals), sociology (inevitably Ervin Goffman) and philosophy, including the current developments in material semiotics on the 'phenotypic other' as a relational construct (M'charek et al. 2014b).

4. This is historically rooted for example in the professional photography of human 'exhibits' at universal exhibitions in colonial times. Even in the work of the first female photographers, such as Jessie Tarbox Beals, racial and gender stereotypes populate such imperialist imageries. For example, Beal's work at the St. Louis Purchase Exposition, the 1904 World's Fair, where she portrayed Native Americans, Ainu women and children, and fairgoers interacting with "Negrito" men at the Anthropology Exhibit (Jessie Tarbox Beals collection, Schlesinger Library, Radcliffe Institute for Advanced Study, Harvard University. Previews available online through the Schlesinger catalogue: URL http://preserve.harvard.edu/photographs/Schlesinger\% 20Library.html) (Accessed 29 January, 2019).

5. Alllooksame? http://alllooksame.com/ (accessed 29 January, 2019).

6. https://www.flickr.com/groups/facity/ (accessed 29 January, 2019).

7. http://www.facity.com/facity_instruction.pdf To the frequently asked question "Why are you doing all this?", the artists' response is "We have called Facity into life because we wanted to show faces in a way one has not seen before. Close, direct, intimate, naked, natural, genuine". Facity follows a protocol for the photo shoot: frontal position, no smile, minimum make-up, minimum of hair visible, no clothing visible. 
8. http://facity.com/faq/

9. http://kipfulbeck.com/the-hapa-project/samples/ (accessed 29 January, 2019).

10. http://thisisus.co.il/ (accessed 29 January, 2019).

11. https://vimeo.com/18432535 (accessed 29 January, 2019).

12. http://thisisus.co.il/ See also the Facebook page of the project https://www.facebook.com/ thisisusisrael (accessed 29 January, 2019).

13. These categories are quoted verbatim from the project's website. The project demo is online at https://www.youtube.com/watch?v=pDPc01Xk75A (accessed 29 January, 2019).

14. Interview, Roee Lotan, Sept. 3rd 2011. Many thanks to Naor Ben-Yehoyada, Arik Bernstein and Roee Lotan for speaking with me about this project.

15. Many thanks to Joanne Rappaport for this private communication of 4 t September 2011.

16. Many thanks to Ildikó Plájás for sharing her investigation on 'visual technologies of sorting population and policing mobility in Europe', with specific reference to the Roma.

17. In fact, Wittgenstein "family resemblance" recalls in many ways the method proposed by John Austin, for studying excuses as a key act in linguistic competence: "to examine excuses is to examine cases where there has been some abnormality or failure: and as so often, the abnormal will throw light on the normal, will help us to penetrate the blinding veil of ease and obviousness that hides the mechanisms of the natural successful [linguistic] act" (Austin 1956: 5-6).

18. By comparison, cf. Shapin (2003) on the importance of calibrating heritage foods to containers for the success of their dissemination in the international markets.

\section{ABSTRACTS}

Based on an ethnographic approach as well as on cultural critique of relevant digital projects, this article confronts visual 'ecologies of belonging'. Building on my 'skilled visions' approach, I propose a critical study of everyday visual apprenticeship of social and cultural stereotypes about looking. The main finding is that the act of looking and categorizing self and others should be understood as a form of relational and situated learning, rather than as a problem of (facial) recognition. The self-assertion with which we orient ourselves in a social environment on an everyday basis is telling of the enchanted quality of 'making-believe', as our own skilled vision makes us believe that it is indeed possible to sort and chart sociocultural groups on the basis of phenotypic classifications. However, the evidence of such 'mugshot aesthetics' is at best ambivalent. The mugshot view reduces our social abilities of reading complex and cultural cues to standard mechanisms, and 'makes us believe' that a perspicuous view of human types is achievable and indeed operationalizable in technologies of vision. The article proposes a more complex attitude to this issue based both on ethnographic interaction - including fieldwork, indepth interviews and visual analysis.

Fondé sur une approche ethnographique ainsi que sur des réflexions critiques émises dans le cadre de projets numériques pertinents, cet article confronte les différentes modalités visuelles de "l'écologie de l'appartenance". A partir de mes recherches sur " les compétences visuelles", je propose une étude critique de l'apprentissage visuel des stéréotypes sociaux et culturels propres au "regarder". Le principal résultat est que l'acte de regarder et de catégoriser soit soi même soit les autres devrait être compris comme une forme d'apprentissage contextualisé et relationnel plutôt que comme un problème de reconnaissance (faciale). L'affirmation de soi, avec laquelle 
nous nous orientons dans un environnement social dans la vie quotidienne, nous révèle les qualités d'enchantement du "faire croire" comme nos propres compétences visuelles nous font croire que nous pouvons trier et ranger les groupes socio-culturels sur la base d'une classification phénotypique. Cependant, l'évidence de ces "clichés esthétiques" est plutôt ambivalent. Ces clichés réduisent nos propres compétences, à lire des indices visuels complexes, à des mécanismes normatifs et nous font croire qu'un vision claire des types humains est possible et de fait opérationnelle au sein des technologies propres à la vision. Cet article propose un positionnement plus complexe face à ces questions fondées tant sur des interactions ethnographiques lors du terrain et des interviews approfondis que sur des analyses visuelles.

Basado en un enfoque etnográfico, así como en la crítica cultural de proyectos digitales relevantes, este artículo confronta diferentes "ecologías visuales de pertenencia". Sobre la base de mi enfoque sobre las "visiones competentes", propongo un estudio crítico del aprendizaje visual cotidiano de los estereotipos sociales y culturales sobre la mirada. El principal argumento es que el hecho de verse y categorizarse a sí mismo y a los demás debe entenderse como una forma de aprendizaje relacional y situado, en lugar de un problema de reconocimiento (facial). La auto-convicción con la que nos orientamos en el entorno social todos los días da prueba de la calidad encantada de "hacer creer", ya que nuestra visión competente nos hace creer que, de hecho, es posible clasificar y ubicar grupos socioculturales sobre la base de clasificaciones fenotípicas. Sin embargo, la evidencia de tal "estética de la fotografía policial" es, en el mejor de los casos, ambivalente. La vista instantánea reduce nuestras habilidades sociales de lectura de señales complejas y culturales en patrones estandarizados, y "nos hace creer" que una visión clara de los tipos humanos es factible y, de hecho, operativa dentro de las tecnologías de la visión. El artículo propone una actitud más compleja sobre este tema basada tanto en la interacción etnográfica, incluyendo el trabajo de campo, como en las entrevistas en profundidad y en el análisis visual.

\section{INDEX}

Mots-clés: compétences visuelles, faire croire, clichés esthétiques, écologies de l'appartenance.

Palabras claves: visiones competentes, hacer creer, clichés estéticos, ecologías de la pertenencia Keywords: skilled visions, making believe, mugshot aesthetics, ecologies of belonging

\section{AUTHOR}

\section{CRISTINA GRASSENI}

University of Leiden, Faculty of Social Sciences, Institute of Cultural Anthropology and Development Sociology

c.grasseni@fsw.leidenuniv.nl

Cristina Grasseni is Professor of Anthropology at Leiden University and works on visual, political and economic anthropology (see her monographs Developing Skill, Developing Vision, 2009, Beyond Alternative Food Networks, 2013, and The Heritage Arena, 2017). 